\title{
A proteção internacional dos direitos político-eleitorais: o caso Lopez Mendoza vs Venezuela e a inconvencionalidade da alínea "G" da Lei de Inelegibilidades
}

\author{
Protecting international political-electoral \\ rights: the case Lopez Mendoza vs Venezuela and \\ the inconventionality of item " $G$ " of the Ineligibil- \\ ity Law
}

\author{
Sandro Alex de Souza Simões ${ }^{1}$ \\ Pedro Henrique Costa de Oliveira ${ }^{2}$
}

1 Doutor pela Università Del Salento/Lecce, Itália, cursando atualmente Pós-doutorado na Faculdade de Direito da Universidade de Lisboa, Portugal. Mestre em Direito pela Universidade Federal do Pará. Especialista em Bioética pela Università Del Sacro Cuore-Roma, Itália. É professor titular de História do Direito e do Pensamento Jurídico (graduação) e de Sistemas Internacionais de Proteção aos Direitos Humanos (mestrado) do Centro Universitário do Estado do Pará, no qual foi Coordenador do curso de graduação em direito (2002-2006 e 2009-2016). Procurador Federal da Procuradoria Geral Federal/AGU junto à Universidade Federal do Pará.

E-mail: prof.sandroalex@gmail.com

2 Mestrando em Direitos Humanos e Políticas Públicas do PPGD/CESUPA. Especialista em Direito Público pela Pontifícia Universidade Católica de Minas Gerais - PUC Minas e em Direito Eleitoral pelo Instituto Brasiliense de Direito Público - IDP. Professor do curso de pós-graduação lato sensu em Direito Eleitoral da UNAMA. Presidente da Comissão de Direito Eleitoral da OAB/PA. Bacharel em Direito pelo Centro Universitário do Estado do Pará - CESUPA. Membro-fundador da Academia Brasileira de Direito Eleitoral e Político - ABRADEP. Advogado. E-mail: pedrohco@hotmail.com 
Resumo: O presente estudo pretende fazer uma aferição de convencionalidade da alínea " $\mathrm{g}$ " do inciso I do art. $1^{\circ}$ da LC 64/90 - Lei de Inelegibilidades -, alterada pela LC n. ${ }^{\circ}$ 135/2010, popularmente conhecida como Lei da Ficha Limpa, cuja compatibilidade constitucional foi declarada pelo Supremo Tribunal Federal, no julgamento da Ação Direta de Inconstitucionalidade 4.578 e das Ações Declaratórias de Constitucionalidade $\mathrm{n}^{\circ} 29$ e 30 . A partir da teoria do Controle Jurisdicional de Convencionalidade - inaugurada no Brasil a partir da tese de doutoramento do Professor Valerio Mazzuoli, da UFMT, em 2008 -, busca-se, aqui, analisar a possibilidade de aplicação dos tratados internacionais de direitos humanos dos quais o Brasil é signatário, paralisando o efeito de uma norma interna, mesmo após a declaração de constitucionalidade pela Corte Suprema brasileira, levando em consideração que o STF se olvidou na realização de um duplo controle de compatibilidade material vertical (adequação da lei em relação à Constituição Federal e aos tratados internacionais de direitos humanos).

Palavras-chaves: Controle de Convencionalidade. Lei da Ficha Limpa. Corte Interamericana de Direitos Humanos. Tratados internacionais de Direitos Humanos. Direito Internacional dos Direitos Humanos.

Abstract: This study aimed to conventionality measurement of item " $\mathrm{g}$ " of Part I of Art. 1 of the LC 64/90 - Ineligibility Law - as amended by LC No. 135/2010, whose constitutional compatibility was declared by the Supreme Court in the trial of the direct action of unconstitutionality 4578 and declaratory actions of Constitutionality 29 and 30. from the theory of Jurisdictional Control Conventionality - inaugurated in Brazil from the doctoral thesis of professor Valerio Mazzuoli, UFMT in 2008 - is sought here, examine the 
possibility of implementation of international human rights treaties to which Brazil is a signatory, paralyzing the effect of an internal standard, even after the declaration of constitutionality by the Court Brazilian Supreme, taking into account the Supreme Court we have forgotten the realization of a dual control material compatibility vertical (adequacy of the law in relation to the Federal Constitution and international human rights treaties).

Keywords: Conventionality control. Complementary Law n. ${ }^{\circ}$ 135/2010. Inter-American Court of Human Rights. International Human Rights Treaties. International Law of Human Rights.

\section{Introdução}

A Lei Complementar 135/2010, popularmente conhecida como "Lei da Ficha Limpa", que alterou a LC 64/90 - a chamada Lei de Inelegibilidades -, desde que se encontrava em fase de processo legislativo, já despertava acalorados debates sobre a sua (não) adequação à ordem constitucional.

Tão logo passou a viger, teve sua constitucionalidade questionada no Supremo Tribunal Federal, instrumentalizada por meio da Ação Direta de Inconstitucionalidade 4.578 e das Ações Declaratórias de Constitucionalidade no 29 e 30, que traziam, nos seus bojos, violação à irretroatividade das leis, coisa julgada, ato jurídico perfeito e presunção de inocência. Naquela oportunidade, o Pretório Excelso declarou a constitucionalidade da Lei da Ficha Limpa, afastando, por conseguinte, a tese de inconstitucionalidade, ratificada em março de 2018, quando, novamente, o STF se deparou com a discussão da aplicação da Lei em casos ocorridos antes de sua promulgação, em 2010. 
Em prestígio aos princípios da probidade administrativa, normalidade e igualdade nas eleições (art. 14 da CF/88) e do preceito da prestação e higidez de contas, o STF rechaçou as alegadas violações à irretroatividade das leis, coisa julgada e ato jurídico perfeito, proteção da confiança ao administrado, direito adquirido, presunção de inocência, devido processo legal, princípios da segurança jurídica, da vedação ao retrocesso e da proporcionalidade, bem como do núcleo essencial dos direitos políticos.

O acórdão proferido no julgamento das ações de controle concentrado de constitucionalidade supramencionadas, afirma o verdadeiro propósito moralizante da Lei da Ficha Limpa.

Passados oito anos de sua promulgação, os debates em torno da aplicação da Lei da Ficha Limpa ainda não cessaram. Ao revés, continuam, agora não só questionando sua adequação - ou não - à Constituição Federal, mas também aos tratados internacionais de direitos humanos, dos quais o Brasil é signatário - como é o caso da Convenção Americana de Direitos Humanos $(\mathrm{CADH})$ ou Pacto de São José da Costa Rica.

Parte-se, aqui, do pressuposto de que a Lei da Ficha Limpa, ainda que declarada constitucional pelo Supremo, viola princípios basilares, estruturantes do direito, bem como dispositivos convencionais, o que a tornaria inválida, ante o efeito paralisante dos tratados internacionais de direitos humanos. É dizer, a norma continua vigente no ordenamento jurídico, mas não possui validade. Isso se dá pelo fato de que as Constituições latino-americanas estabelecerem cláusulas abertas, que permitem a integração entre a ordem constitucional e a internacional, especialmente em matéria de direitos humanos, ampliando e expandindo o bloco de constitucionalidade. Ao processo de constitucionalização do 
Direito Internacional conjuga-se o de internacionalização do Direito Constitucional ${ }^{3}$.

Ante o exposto, problematiza-se: à luz dos dispositivos convencionais estabelecidos nos tratados internacionais de direitos humanos dos quais o Brasil é signatário, é a LC n ${ }^{\circ}$ 64/90, com alterações trazidas pela LC 135/2010, (in)convencional?

Outrossim, mister ressaltar a relevância de uma leitura do Direito Eleitoral não só com os óculos da Constituição - posição de centralidade da Constituição Federal no ordenamento jurídico pátrio -, mas também à luz das normas internacionais de proteção dos direitos humanos, mormente à medida que se identifica um movimento ainda incipiente - para não dizer embrionário - na doutrina brasileira no trato com as questões pertinentes ao Direito Eleitoral Internacional.

O presente artigo analisa a (in)convencionalidade da restrição aos direitos políticos - enquanto direitos humanos fundamentais - por decisões tomadas em âmbito administrativo, especificamente por rejeição de contas do gestor pelo Tribunal de Contas, hipótese da alínea "g" da Lei de Inelegibilidades, tendo a Convenção Americana de Direitos Humanos e a interpretação dada pela Corte Interamericana de Direitos Humanos (intérprete última, mais autorizada e definitiva do Pacto de São José) no Caso Lopez Mendoza vs Venezuela como paradigmas.

\section{Da hierarquia dos tratados internacionais de direitos humanosna ordem jurídica interna}

A Constituição Federal de 1988 é um marco no processo de redemocratização e institucionalização dos direitos huma-

3 PIOVESAN, 2012, p. 69. 
nos no Brasil. Seu advento inicia o processo de abertura da ordem jurídica interna, com a incorporação dos tratados de direitos humanos no país. O desenvolvimento desse processo de incorporação de direitos humanos previstos em diplomas internacionais; a abertura a essa nova ordem se deu a cada vez mais intensa ratificação, pelo Brasil, de várias normas convencionais globais e regionais de proteção dos direitos humanos.

No escólio de Marcelo Peregrino ${ }^{4}$,

A questão da hierarquia dos tratados de direitos humanos - diga-se - é matéria de relevância interna tão somente, isto é, da incidência normativa do diploma internacional num dado território. No plano internacional, relevante é a adesão do Estado, sendo qualquer descumprimento do tratado visto como violação ao Direito Internacional.

A doutrina aponta para a existência de quatro correntes acerca da hierarquia dos tratados internacionais de proteção dos direitos humanos: 1) a hierarquia supraconstitucional dos tratados; 2) a hierarquia constitucional; 3) a hierarquia supralegal; e 4) mesma hierarquia das leis federais.

Constituições como as da Bolívia, Colômbia e Guatemala colocam os tratados internacionais em posição de proeminência em relação ao direito interno, gozando tais diplomas, por conseguinte, de hierarquia supraconstitucional.

O Brasil, atualmente, já ratificou praticamente todos os tratados internacionais significativos sobre direitos humanos pertencentes ao sistema global de proteção dos direitos humanos (sistema das Nações Unidas). No que se refere ao sistema interamericano, o Brasil segue a mesma linha, sendo parte de praticamente todos os tratados continentais, a exemplo do Pacto de São José da Costa Rica, de 1969.

4 FERREIRA, 2015, p. 61. 
Essa abertura a uma nova ordem foi possível pela inédita redação do $\S 2^{\circ}$ do art. $5^{\circ}$, da $\mathrm{CF}$, estatui que:

Os direitos e garantias expressos nesta Constituição não excluem outros decorrentes do regime e dos princípios por ela adotados, ou dos tratados internacionais em que a República Federativa do Brasil seja parte (grifo nosso).

Sobre o tema, precisas são as lições de Ingo Sarlet ${ }^{5}$, quando aduz que:

A norma contida no $\S 2^{\circ}$ do art. $5^{\circ}$ da CF traduz o entendimento de que, além dos direitos expressamente positivados no capítulo constitucional próprio (dos direitos e garantias fundamentais), existem direitos que, por seu conteúdo e significado, integram o sistema da Constituição, compondo, em outras palavras, na acepção originária do direito constitucional francês, o assim chamado bloco de constitucionalidade, que não se restringe necessariamente a um determinado texto ou mesmo conjunto de textos constitucionais, ou seja, não se reduz a uma concepção puramente formal de constituição e de direitos fundamentais. Assim, a despeito do caráter analítico do Título II da $\mathrm{CF}$, onde estão contidos os direitos e garantais como tal designados e reconhecidos pelo constituinte, cuida-se de uma enumeração não taxativa. $\mathrm{O}$ art. $5^{\circ}$, $\S 2^{\circ}$, da $\mathrm{CF}$, representa, portanto, uma cláusula que consagra a abertura material do sistema constitucional de direitos fundamentais como sendo um sistema inclusivo e amigo dos direitos fundamentais.

Na esteira do que defende Sarlet, os direitos fundamentais previstos na Constituição da República Federativa do Brasil, portanto, não são taxativos, principalmente aqueles previstos no rol do art. $5^{\circ}$, tendo em vista que, a partir da incorporação dos tratados internacionais - os quais integram o chamado bloco de constitucionalidade -, tais normas são paradigmas aptos a instaurar um sistema de controle de convencionalidade em face da legislação doméstica, objeto de estudo a seguir.

$5 \quad$ SARLET, 2013, p. 517 
Nessa senda, Cançado Trindade se filia à corrente que defende a hierarquia constitucional dos tratados internacionais de proteção dos direitos humanos na ordem jurídica interna:

O disposto no artigo 5 (2) da Constituição Brasileira de 1988 se insere na nova tendência de Constituições latino-americanas recentes de conceder um tratamento especial ou diferenciado também no plano do direito interno aos direitos e garantias individuais internacionalmente consagrados. A especificidade e o caráter especial dos tratados de proteção internacional dos direitos humanos encontram-se, com efeito, reconhecidos e sancionados pela Constituição brasileira de 1988: se, para os tratados internacionais em geral, se tem exigido a intermediação pelo Poder Legislativo de ato com força de lei de modo a outorgar as suas disposições, vigência ou obrigatoriedade no plano do ordenamento jurídico interno, distintamente no caso dos tratados de proteção internacional em que o Brasil é Parte os direitos fundamentais nele garantidos passam, consoante os artigos 5 (2) e 5 (1) da Constituição Brasileira de 1988, a integrar o elenco dos direitos constitucionalmente consagrados e direta e imediatamente exigíveis no plano do ordenamento jurídico interno ${ }^{6}$.

Cançado Trindade rejeita, por conseguinte, a tese de equiparação normativa dos tratados de direitos humanos com a legislação infraconstitucional:

A tese da equiparação dos tratados de direitos humanos à legislação infraconstitucional - tal como ainda seguida por alguns setores em nossa prática judiciária - não só representa um apego sem reflexão a uma postura anacrônica, já abandonada em vários países, mas também contraria o disposto no art. 5(2) da Constituição Federal brasileira. Se se encontrar uma formulação mais adequada - e com o mesmo propósito - do disposto no art. 5(2) da Constituição Federal, tanto melhor; mas enquanto não for encontrada, nem por isso está o Poder Judiciário eximido de aplicar o art. 5(2) da Constituição. Muito ao contrário, se alguma incerteza houver, encontra-se no dever de dar-lhe a interpretação

6 CANÇADO TRINDADE, 1996, p. 211. 
correta, para assegurar sua aplicação imediata; não se pode deixar de aplicar uma disposição constitucional sob o pretexto de que não parece clara ${ }^{7}$.

Por autorização constitucional, portanto, os tratados internacionais de direitos humanos ratificados pelo Brasil são incorporados ao ordenamento jurídico interno com status constitucional.

Veja-se, por exemplo, entendimento de Mazzuoli ${ }^{8}$ sobre o tema:

Com base neste dispositivo, que segue a tendência do constitucionalismo contemporâneo, sempre defendemos que os tratados internacionais de direitos humanos ratificados pelo Brasil têm índole e nível constitucionais, além de aplicação imediata, não podendo ser revogados por lei ordinária posterior. E a nossa interpretação sempre foi a seguinte: se a Constituição estabelece que os direitos e garantias nela elencados "não excluem" outros provenientes dos tratados internacionais "em que a República Federativa do Brasil seja parte", é porque ela própria está a autorizar que esses direitos e garantias internacionais constantes dos tratados de direitos humanos ratificados pelo Brasil "se incluem" no nosso ordenamento jurídico interno, passando a ser considerados como se escritos na Constituição estivessem.

Com efeito, noutras palavras, a Constituição permitiu a ampliação do bloco de constitucionalidade com a inclusão de direitos e garantias que podem não estar escritos no corpo do texto constitucional, mas que o integram como se nele estivessem positivados.

A partir da Carta Política de 1988, com a disposição trazida no art. $5^{\circ}, \S 2^{\circ}$, passou-se a reconhecer uma dupla fonte normativa advinda dos direitos, quais sejam: (1) interno, decorrente dos direitos expressos e implícitos na Constituição - direitos e garantias decorrentes do regime e dos

7 CANÇADO TRINDADE, 2003, p. 624.

8 MAZZUOLI, 2013a, p. 34-35. 
princípios por ela adotados; e (2) internacional, decorrente dos tratados internacionais que a República Federativa do Brasil seja parte.

De forma expressa, há atribuição constitucional, aos tratados internacionais de proteção dos direitos humanos, a condição de fonte do sistema constitucional de proteção de direitos, no mesmo plano de igualdade e eficácia daqueles expressamente nela previstos. Com essa dualidade de fontes - interna e internacional -, eventual conflito entre normas deve ser resolvido aplicando-se aquela que seja mais favorável ao indivíduo - princípio pro homine -, pois, conforme leciona Mazzuoli ${ }^{9}$, "o que se visa é a otimização e a maximização dos sistemas (interno e internacional) de proteção dos direitos humanos".

A cláusula aberta da norma insculpida no art. $5^{\circ}, \S 2^{\circ}$, da CF, admite, portanto, a incorporação dos tratados internacionais de direitos humanos com status constitucional. Há quem defenda, ao revés, que as normas convencionais estão em posição superior na hierarquia normativa, para os quais tais diplomas internacionais possuem natureza jurídica supraconstitucional.

Nessa esteira, aduz Mazzuoli ${ }^{10}$ que:

[...] em sede doutrinária também não faltaram vozes que, dando um passo mais além do nosso, defenderam cientificamente o status supraconstitucional dos tratados de proteção dos direitos humanos, levando-se em conta toda a principiologia internacional marcada pela força expansiva dos direitos humanos e pela sua caracterização como normas de jus cogens internacional.

Dissertando sobre a cláusula constitucional aberta, Piovesan aduz que "os direitos internacionais integrariam, assim, o chamado 'bloco de constitucionalidade', densifi-

9 Ibid., p. 36.

10 Ibid., p. 37. 
cando a regra constitucional positivada no $\S 2^{\circ}$ do art. $5^{\circ}$ [da CF/88]". ${ }^{11}$

Para o juspositivista Kelsen ${ }^{12}$, a ordem jurídica não se conforma por um sistema de normas ordenadas em um plano horizontal, no mesmo plano, mas, sim, é conformada por uma construção escalonada de normas, em que se pode observar a Constituição - Norma Fundamental - no topo dessa pirâmide normativa, na qual as demais normas do ordenamento buscam seu fundamento último de validade.

$\mathrm{Na}$ esteira de Antonio Maués ${ }^{13}$, Kelsen centraliza o problema da defesa da Constituição na "busca de garantias do exercício regular das funções estatais, de acordo com sua concepção da estrutura hierárquica da ordem jurídica".

Bobbio $^{14}$, por seu turno, assevera que uma norma somente é válida quando pode ser reconduzida à norma fundamental. Nessa senda, a "pertencência" de uma norma na ordem jurídica pressupõe sua sujeição e observância à normal fundamental, a qual é o fundamento de validade de todas as normas do sistema.

A partir, contudo, da introdução dos tratados internacionais de direitos humanos no ordenamento jurídico brasileiro, a estrutura piramidal kelzeniana sofre substancial modificação, seguindo o entendimento de internacionalistas como Cançado Trindade ${ }^{15}$ e Flávia Piovesan ${ }^{16}$, os quais defendem que tais instrumentos normativos compõem o bloco de constitucionalidade, possuindo, portanto, hierarquia constitucional.

11 PIOVESAN, 2015, p. 121.

12 KELSEN, 2009, p. 247.

13 MAUÉS, 2010, p. 360.

14 BOBBIO, 2007, p. 210.

15 CANÇADO TRINDADE, 2003.

16 PIOVESAN, 2015. 
Já Eduardo Ferrer Mac-Gregor ${ }^{17}$, Juiz da Corte Interamericana de Direitos Humanos, aduz que os diálogos dos direitos e garantias previstos nas constituições nacionais se revelaram insuficientes. A necessidade de os Estados nacionais conjuntamente emitirem documentos internacionais em que se reconhecessem direitos humanos em padrão internacional e estabelecessem órgãos de supervisão e controle, restou patente depois do sofrimento da humanidade ao terminar a Segunda Guerra Mundial, conforme apontam os próprios considerandos da Carta da Organização das Nações Unidas (ONU).

Ante esse estado de coisas, segundo Mac-Gregor ${ }^{18}$, começa-se um processo de internacionalização do direito constitucional (dos direitos humanos). O direito internacional, que antes estava fundamentado apenas na relação entre os Estados, e não na proteção do indivíduo, inicia uma importante transformação. Assim, surge o direito internacional dos direitos humanos, em que a interação entre os direitos internacional, constitucional e processual resulta evidente, o que também provoca novos entendimentos em relação ao conceito tradicional de soberania e dos Estados nacionais, engendrados principalmente no século XVII.

Com efeito, verificando a crise do paradigma tradicional e a emergência de um novo, a guiar a cultura jurídica latino-americana, estar-se-ia diante de uma estrutura graficamente semelhante à de um trapézio, e não mais uma piramidal, com a Constituição e os tratados internacionais de direitos humanos no ápice da ordem jurídica ${ }^{19}$.

No entanto, o Brasil, desde meados de 2008, concluiu uma série de julgamentos que modificaram, sobremaneira,

17 FERRER MAC-GREGOR, 2011, p. 537.

18 FERRER MAC-GREGOR, Op. cit., p. 538.

19 PIOVESAN, Op. cit., mesma página. 
a concepção do nível hierárquico que têm os tratados internacionais de direitos humanos no direito brasileiro.

Desde o final da década de 1970, o entendimento pretoriano do STF era no sentido de que os tratados tinham o mesmo nível hierárquico das leis ordinárias, o que era deveras criticado pela doutrina internacionalista.

A partir do julgamento que paralisou a validade da norma constitucional que prevê a prisão civil do depositário infiel, o Pretório Excelso precisou reformular seu entendimento. Quando do julgamento em conjunto do Habeas Corpus (HC) no 87.585 e dos Recursos Extraordinários (RE) no 466.343 e 349.703 , de 2008, o Supremo conferiu aos tratados internacionais de direitos humanos natureza supralegal, situando-os acima das leis ordinárias, porém abaixo da Constituição Federal. Vale ressalar que para a minoria, à época do julgamento, os tratados deveriam integrar o bloco de constitucionalidade, tendo, por conseguinte, hierarquia constitucional.

Na esteira de Maués ${ }^{20}$, "o novo entendimento tem chamado a atenção da doutrina, que aponta a necessidade de que o STF desenvolva um diálogo com outros tribunais, especialmente a Corte Interamericana, ou exerça o controle de convencionalidade das leis".

Salienta, ainda, que "as obrigações assumidas pelo Estado ao ratificar um tratado de direitos humanos impõem examinar se o conjunto de atos praticados pelos poderes públicos, inclusive aqueles de caráter legislativo, respeitam as disposições do tratado" 21 .

Esse quadro insatisfatório levou a doutrina mais abalizada a qualificar de "'lamentável falta de vontade' do

20 MAUÉS, 2013, p. 216.

21 MAUÉS. Op. cit., p. 226. 
Poder Judiciário a não aplicação devida do $§ 2 .^{\circ}$ do art. 5. ${ }^{\circ}$ da Constituição".

Irrelevante o rito pelo qual determinado tratado de direitos humanos foi aprovado no Brasil para verificação de seu status hierárquico. A única diferença entre um tratado de direitos humanos aprovado pelo rito do $\S 3^{\circ}$ do art. $5^{\circ}$, da CF, é que este último serve de paradigma para controle concentrado de convencionalidade, enquanto que aquele ratificado sem a observância do rito do $\S 3^{\circ}$ serve de paradigma para controle difuso de convencionalidade. É dizer, os tratados internacionais de direitos humanos aprovados pelo rito do $\S 3^{\circ}$ são formal e materialmente constitucionais, enquanto que os demais são apenas materialmente constitucionais.

\section{A relação entre controle de convencionalidade e os chamados blocos de constitucionalidade}

No Brasil, o debate em torno da interação entre a ordem interna e a internacional deve passar, inarredavelmente, pelo enfrentamento de temas correlatos, quais sejam: o "bloco de constitucionalidade" e o "controle de convencionalidade" 22 .

Tais conceitos representam importantes mecanismos de interação entre as ordens jurídicas interna e internacional, bem como fortalecem a gramática de proteção dos direitos humanos, de modo que o bloco de constitucionalidade representa como "o direito interno vê o direito internacional", e o controle de convencionalidade representa como "o direito internacional vê o direito interno".

Louis Favoreu ${ }^{23}$, prestigiado jurista francês - foi quem, na década de 1970, difundiu a noção de bloco de constitucio-

22 BASTOS JUNIOR; CAMPOS, 2011, p. 3.

23 FAVOREU, 1990, p. 59-60. 
nalidade (bloc de constitutionnalitê) no direito constitucional francês -, leciona que:

Puede considerarse que la noción de bloque de constitucionalidade ha cumplido su misión: hacer que se tome conciencia de esta unidad y provocar la fusión progresiva de las diferentes piezas del conjunto. Em último término, podría llegar a desaparecer si los franceses se acostumbraran a hablar globalmente de la Constitución para designar el conjunto de textos que forman el bloque de constitucionalidad.

O bloco de constitucionalidade excede a Constituição escrita para designar princípios e normas com valor constitucional que servem de parâmetro de controle de constitucionalidade.

Acerca disso, Bastos Junior e Campos ${ }^{24}$ dissertam que:

A partir desta construção, é possível identificar, com Canotilho (2003), duas acepções para determinação do parâmetro constitucional, em relação ao qual todos os atos normativos devem guardar conformidade: (a) o parâmetro constitucional equivalente à constituição escrita ou leis com valor constitucional formal, caso em que a aferição da conformidade dos atos normativos, sob o prisma de sua constitucionalidade ou inconstitucionalidade, somente pode ser feita com base em normas e princípios escritos na constituição ou em outras leis formalmente constitucionais; (b) o parâmetro constitucional equivalente à ordem constitucional global, hipótese em que o juízo de legitimidade constitucional dos atos normativos pode ser feito não apenas com fundamento nas normas e princípios escritos das leis constitucionais, mas levando em conta também princípios não escritos integrantes da ordem constitucional global.

Nessa senda, o bloco de constitucionalidade se insere na segunda opção, cujo reconhecimento de regras e valores constitucionais estão além do texto escrito na Constituição.

Noutras palavras, o "bloco de constitucionalidade

24 BASTOS JUNIOR; CAMPOS, Op. cit., p. 7. 
excede a Constituição escrita, buscando valores maiores que servirão de orientação para as normas constitucionais escritas" 25 .

O controle de convencionalidade é o mecanismo que se exerce para verificar a compatibilidade, adequação de um ato normativo interno - lei, regulamento, etc. - com as normas, princípios e obrigações estabelecidas nos tratados internacionais de direitos humanos dos quais determinado Estado é signatário. No nosso caso, o Brasil.

Cumpre ressaltar que a literatura brasileira no que se refere ao controle de convencionalidade ainda é escassa, mormente quando buscamos fazer uma comparação da legislação eleitoral brasileira com a ordem internacional, o que justifica sobremaneira a relevância desse estudo. $\mathrm{O}$ grande expoente da doutrina internacionalista que se propôs a realizar profícua pesquisa no âmbito do controle de convencionalidade, foi o professor da Universidade Federal do Mato Grosso (UFMT), Valério de Oliveira Mazzuoli, quando da defesa de sua tese de doutoramento.

No entendimento de Mazzuoli ${ }^{26}$, a compatibilidade do direito interno com os tratados internacionais de direitos humanos em vigor no país faz-se por meio do controle de convencionalidade, que é complementar e coadjuvante do controle de constitucionalidade.

Ressalta, ainda, o doutrinador, que:

A expressão 'Controle de Convencionalidade' ainda é pouco conhecida no Brasil, não tendo sido objeto de qualquer estudo entre nós até o presente momento. O Controle de Convencionalidade tem por finalidade compatibilizar verticalmente as normas domésticas (as espécies de leis, lato sensu, vigentes no país) com os tratados internacionais de Direitos Humanos ratificados pelo

25 COELHO, 1994, p. 263.

26 MAZZUOLI, 2013b, p. 31. 
Estado e em vigor no território nacional. Já o controle de supralegalidade, que estudaremos mais à frente, é a compatibilização das leis com os tratados internacionais comuns que se situam acima delas, por deterem status supralegal. ${ }^{27}$

Nesse sentido, o controle de convencionalidade deve ser exercido pelos órgãos da justiça nacional relativamente aos diplomas internacionais aos quais o país se encontra vinculado. Trata-se de adaptar ou conformar os atos normativos internos aos compromissos internacionalmente assumidos pelo Estado, que criam para este deveres no plano internacional com reflexos práticos no plano do direito doméstico ${ }^{28}$.

Em seus estudos, Mazzuoli, acompanhando o entendimento da Corte Interamericana, identifica o poder/dever do exercício do controle difuso de convencionalidade das leis por qualquer magistrado, de primeiro ou de segundo grau, seja da justiça estadual, seja da federal, inclusive os magistrados que compõem todos os tribunais superiores ${ }^{29}$.

Dentro do sistema normativo brasileiro, Mazzuoli leciona que, para além do controle difuso, também há o controle concentrado de convencionalidade, pelo STF, na hipótese restrita dos tratados de direitos humanos obterem aprovação pelo rito especial do artigo $5^{\circ}, \S 3^{\circ}$, da Constituição Federal de $1988^{30}$.

Na medida em que um tribunal constitucional exerce, contenciosamente, o controle de constitucionalidade das leis, um internacional exerce, no exercício de sua competência contenciosa, o controle de convencionalidade.

A Corte Interamericana de Direitos Humanos (Corte IDH), quando do julgamento do caso Tibi vs. Equador, espe-

27 MAZZUOLI, 2011, p. 134.

28 MAZZUOLI, 2013 b, p.32.

29 ALAMAR, 2015, p. 36.

30 Ibid., mesma página. 
cificamente por meio do voto do seu então presidente, Juiz Sergio García Ramírez, deixou clarividente no que consiste essa obrigação ${ }^{31}$.

O controle de convencionalidade:

[...] implica valorar los actos de la autoridad interna a la luz del Derecho Internacional de los derechos humanos, expressados en tratados o convenciones e interpretado, em su caso, por los órganos supranacionales que poseenesta atribución. Equivale, en su próprio ámbito, al control de constitucionalidad que ejercen los tribunales de esta especialidad (o bien, todos los tribunales en supuestos de control difuso) cuando aprecian un acto desde la perspectiva de su conformidad o incompatibilidade con las normas constitucionales internas. ${ }^{32}$

Cristina Figueiredo Terezo ${ }^{33}$ aduz que a própria manutenção de regra contrária à $\mathrm{CADH}$, desde que afete direitos e liberdades tutelados naquele diploma convencional, corresponde por si só uma violação. Citando Tara Melish, a autora pontua, ainda, que a obrigação de respeito do Estado ao estabelecido na Convenção se aplica, dentre outros, aos direitos civis e políticos.

Nesse viés, Edgar Alamar ${ }^{34}$ assevera que o Estado deve abster-se de produzir, bem como alterar ou revogar leis ou quaisquer atos normativos contrários à $\mathrm{CADH}$, sob pena de

31 CorteIDH. Caso Tibi vs Equador. Exceções Preliminares, Mérito, Reparações e Custas. Sentença de 7 de setembro de 2004. Voto concorrente do juiz Sergio García Ramírez, parágrafo 3.“3. [...] la tarea de la Corte se asemeja a la que realizan los tribunales constitucionales. Estos examinan los actos impugnados --disposiciones de alcance general-- a la luz de las normas, los principios y los valores de las leyes fundamentales. La Corte Interamericana, por su parte, analisa los actos que llegan a su conocimiento enrelación con normas, principios y valores de los tratados en los que funda su competencia contenciosa. Dicho de otra manera, si los tribunales constitucionales controlan la "constitucionalidad", el tribunal internacional de derechos humanos resuelve acerca de la "convencionalidad" de esos actos[...]".

32 MARÍN, 2013, p. 6.

33 TEREZO, 2014, p. 153-154.

34 ALAMAR, 2015, p. 65. 
responsabilização internacional.

Nessa esteira, impende colacionar verbo ad verbum as seguintes lições de Cristina Terezo ${ }^{35}$ :

A obrigação de respeito aos direitos elencados na $\mathrm{CADH}$ deve orientar o exercício da função pública. [...].Outrossim, havendo o cumprimento por agente ou servidor público do Estado de normas que manifestamente sejam contrárias ao teor da Convenção Americana, há responsabilidade internacional do Estado, bem assim se tal ato praticado constituir crime internacional, há de se falar ainda em responsabilidade internacional dos agentes e servidores do Estado.

Com efeito, o controle de convencionalidade reveste-se de ferramenta necessária para o respeito, garantia e efetivação dos direitos insculpidos nas convenções de direitos humanos.

Nessa senda, entende Piovesan ${ }^{36}$ que:

As constituições latino-americanas estabelecem cláusulas constitucionais abertas, que permitem a integração entre a ordem constitucional e a ordem internacional, especialmente no campo dos direitos humanos, expandindo o bloco de constitucionalidade. O sistema regional interamericano simboliza a consolidação de um "constitucionalismo regional", que objetiva salvaguardar direitos humanos fundamentais no plano interamericano. [...]

O controle de convencionalidade pode ser compreendido sob uma dupla perspectiva: tendo como ponto de partida a Corte Interamericana e o impacto de sua jurisprudência no âmbito doméstico dos Estados latino-americanos; e b) tendo como ponto de partida as Cortes latino-americanas e o grau de incorporação e incidência da jurisprudência, principiologia e normatividade protetiva internacional dos direitos humanos no âmbito doméstico ${ }^{37}$.

Para que haja o controle de convencionalidade, é pres-

35 TEREZO, 2014, p. 153.

36 PIOVESAN, Flávia. Op. cit., p. 83.

37 Ibid., p. 83-84. 
suposto básico que os tratados internacionais de direitos humanos tenham hierarquia diferenciada no âmbito interno em relação à legalidade ordinária.

Quando se trata desse assunto, dois são os tipos de controles possíveis, realizados por duas categorias de órgãos. Nesse sentido, faz-se mister trazer à baila os ensinamentos de Roselia Bustilo Marín ${ }^{38}$.

En materia de control de convencionalidad, es necessário tener presente que cuando se hace referencia a este término, se puede hablar de dos cosas que, aunque se conectan encuanto al contenido y procedimento del control, son diferentes encuanto a los órganos que los llevan a cabo. Así, el control de convencionalidad se parte en dos tipos distintos, que son llevados a cabo por dos órganos distintos: el primero es el control concentrado de convencionalidad, que realiza unicamente la Corte Interamericana; el segundo es el control difuso de convencionalidad, que realizan los Estados, en el ámbito de sus competencias a través de todas sus autoridades. (destacados no origional)

Nessa senda, o controle concentrado de convencionalidade é exercido pela Corte Interamericana de Direitos Humanos, quando verifica de forma subsidiária que as disposições internas, as condutas e atos dos Estados-parte são acordes e não violam as disposições da Convenção Americana.

O controle difuso de convencionalidade, por sua vez, sai do âmbito de competência da Corte Interamericana e se insere no âmbito de competência de cada um dos Estados-parte da Convenção Americana. É dizer, dos juízes e tribunais domésticos.

38 MARÍN, Op. cit., p. 7. 


\section{Os direitos políticos na Convenção Americana de Direitos Humanos}

Insta, precipuamente, salientar que os direitos políticos foram positivados no Texto Constitucional de 1988, no Título II, em que repousam os direitos e garantias fundamentais. Por conseguinte, o legislador constituinte, ao verificar a importância do gozo desses direitos para a fruição dos demais direitos, pois sua ausência retiraria da sociedade a possibilidade de participação na construção de decisões políticas, reconheceu a fundamentalidade dos direitos políticos, "não apenas pela topografia expressa na Carta, mas pelo conteúdo que encetam em face da opção do Constituinte de adoção de um regime democrático" ${ }^{\prime 39}$. Tais direitos encontram-se estabelecidos do art. 14 ao 16 da CF/88.

Sobre o tema, Ferreira ${ }^{40}$ pontua que:

É crucial o início do capítulo concernente aos direitos políticos na Constituição afirmar que a soberania popular será exercida pelo sufrágio universal e pelo voto direto e secreto, fortalecendo a concepção e modo pelo qual esses direitos fundamentais se expressam: pelo domínio do povo cujas marcas históricas são relevantes.

Impende destacar que os direitos políticos não se encerram no direito de votar e ser votado, mas se espraiam para qualquer atividade de participação, pelo povo, da construção de políticas públicas e processos deliberativos de tomada de decisões - tais como referendos e plebiscitos -, bem como na iniciativa popular na criação de leis. Decerto que o voto é a expressão maior desse direito, tendo em vista que é por meio desse instrumento fundamental do cidadão que se escolhe os representantes da nação.

39 FERREIRA, 2015, p. 41-42.

40 Ibid., mesma página. 
Numa concepção mais alargada desses direitos, que ultrapassa o capítulo IV do Título II (arts. 14, 15 e 16, da CF/88), as formas de ascensão ao serviço público (art. 37, I e II, da Carta) se inserem na concepção mais ampla desses direitos.

A própria Corte IDH reconheceu no Caso Reverón Trujillo vs Venezuela, a violação dos direitos políticos de uma juíza exonerada de suas funções, no período de deteriorização democrática.

No plano internacional, os direitos políticos encontram-se solenemente estabelecidos na Declaração Americana de Direitos e Deveres do Homem (art. XX), na Declaração Universal dos Direitos do Homem (art. 21), no Protocolo 1 ao Convênio Europeu para a Proteção dos Direitos Humanos e das Liberdades Fundamentais (art. $3^{\circ}$ ), no Pacto Internacional dos Direitos Civis e Políticos (art. 25), na Convenção Americana de Direitos Humanos (art. 23), na Carta Democrática Interamericana $\left(\operatorname{arts.} 2^{\circ}\right.$ e $3^{\circ}$ ), dentre outras convenções internacionais.

A Convenção Americana, por exemplo, traz, em seu artigo 23, as hipóteses de restrição dos direitos políticos ${ }^{41}$.

41 Artigo 23 - Direitos políticos. 1. Todos os cidadãos devem gozar dos seguintes direitos e oportunidades: a) de participar da condução dos assuntos públicos, diretamente ou por meio de representantes livremente eleitos; b) de votar e ser eleito em eleições periódicas, autênticas, realizadas por sufrágio universal e igualitário e por voto secreto, que garantam a livre expressão da vontade dos eleitores; e c) de ter acesso, em condições gerais de igualdade, às funções públicas de seu país. 2. A lei pode regular o exercício dos direitos e oportunidades, a que se refere o inciso anterior, exclusivamente por motivo de idade, nacionalidade, residência, idioma, instrução, capacidade civil ou mental, ou condenação, por juiz competente, em processo penal. (grifo nosso) 
Ferreira ${ }^{42}$ discorre sobre a importância desta norma, porque:

[...] além de assegurar o gozo dos direitos políticos, afirma-se a necessidade do acesso e oportunidade para tanto. A participação nos assuntos públicos e a igualdade na busca pelas funções públicas deve ser vista, também, pela lente do oferecimento de oportunidades para a fruição desses direitos políticos. A "oportunidade" foi definida no Caso Lopez Mendoza vs Venezuela (§ 107) [que será objeto de estudo neste ensaio] como a criação pelo Estado de condições e mecanismos, de "medidas positivas" para a efetividade do direito.

Em face da gravidade dos direitos políticos, a CADH, conforme mencionamos alhures, estabeleceu as únicas hipóteses em que os direitos políticos do cidadão podem ser restringidos, a saber: exclusivamente por motivo de idade, nacionalidade, residência, idioma, instrução, capacidade civil ou mental, ou condenação, por juiz competente, em processo penal. Essa cláusula deve ser lida numerus clausus. O nível da magnitude de tais normas fica ainda mais clarividente quando a $\mathrm{CADH}$, em seu art. $27^{43}$, exclui da possibilidade de suspensão das garantias, em momentos de grave turbação,

42 FERREIRA, 2015, p. 113.

43 Artigo 27 - Suspensão de garantias. 1. Em caso de guerra, de perigo público, ou de outra emergência que ameace a independência ou segurança do Estado-parte, este poderá adotar as disposições que, na medida e pelo tempo estritamente limitados às exigências da situação, suspendam as obrigações contraídas em virtude desta Convenção, desde que tais disposições não sejam incompatíveis com as demais obrigações que lhe impõe o Direito Internacional e não encerrem discriminação alguma fundada em motivos de raça, cor, sexo, idioma, religião ou origem social. 2. A disposição precedente não autoriza a suspensão dos direitos determinados nos seguintes artigos: 3 (direito ao reconhecimento da personalidade jurídica), 4 (direito à vida), 5 (direito à integridade pessoal), 6 (proibição da escravidão e da servidão), 9 (princípio da legalidade e da retroatividade), 12 (liberdade de consciência e religião), 17 (proteção da família), 18 (direito ao nome), 19 (direitos da criança), 20 (direito à nacionalidade) e 23 (direitos políticos), [...] (grifo nosso). 
os direitos políticos, "nem das garantias indispensáveis para a proteção de tais direitos".

Os sistemas internacionais de proteção aos direitos humanos não pretendem impor um modelo eleitoral único aplicável a todos os Estados. Ao revés, estabelecem standards mínimos de proteção desses direitos humanos fundamentais, sempre levando em consideração a singularidade de cada Estado no modo de implementação e organização das eleições. Assim, cada Estado tem a competência de escolher, por exemplo, seu modelo de financiamento de campanhas eleitorais e o sistema eleitoral - se proporcional, distrital, majoritário, misto.

Com efeito, fica a critério afeto a cada Estado estabelecer o modo e o funcionamento dos direitos políticos fundamentais, cuidando os diplomas internacionais, por seu turno, da proteção desses direitos e do regime democrático.

Como dito alhures, a disposição do item 2 do art. 23 da $\mathrm{CADH}$, estabelece, taxativamente, as hipóteses em que os direitos políticos podem sofrer restrições. Mais que isso, fundamentos de ordem moral não são capazes de limitar esses direitos. Marcelo Ferreira ${ }^{44}$, sobre o tema, leciona que:

Ao contrário dos direitos políticos, é de se ressaltar que a liberdade de manifestação e expressão pode, sim, ser mitigada por critérios morais ("moral pública" ou a "proteção moral da infância e da adolescência"), por exemplo, por expressa disposição convencional, de onde se aduz que, quando quis, a Convenção dispôs sobre a matéria. Da mesma maneira, o direito de circulação e de residência que pode ser restrito para a proteção da moral pública (art. 22.3), o direito de reunião (art. 15) e a liberdade de associação (art. 16.2), podem sofrer limitações em nome da moral pública.

44 FERREIRA, 2015, p. 115-116. 
Percebe-se, pois, que, quando quis, a CADH estabeleceu como forma de limitação de alguns direitos, fundamentos de ordem moral. Contudo, o fez expressamente, não o fazendo em relação aos direitos políticos, cuja cláusula restritiva deve ser lida numerus clausus, taxativamente.

O STF, quando do julgamento das representações de inconstitucionalidade da Lei da Ficha Limpa, em várias passagens do acórdão, assentou o "propósito moralizante" da referida legislação infraconstitucional. Falou-se, naquela oportunidade, na lei como um "Estatuto da Moralidade Eleitoral", tudo em desacordo com os parâmetros convencionais de proteção dos direitos políticos - humanos fundamentais -, que não admitem admoestação a esses direitos com base em uma visão moral do mundo, principalmente em uma sociedade tão complexa e plural como a brasileira.

Não se afirma, entretanto, que a probidade não deva ser um critério para a assunção a cargos eletivos, tampouco que o Direito deva ser alheio à Moral, mas tão somente que os representantes eleitos sejam escolhidos, de fato, pelo povo e por outras formas de filtragens que não as de "propósitos moralizantes".

Por fim, enfatiza-se que a elegibilidade de um cidadão somente pode ser afetada - conforme interpretação dada pela Corte IDH à $\mathrm{CADH}$ em relação ao princípio da presunção de inocência - por decisão prolatada por juiz competente em processo penal.

No caso Lopez Mendoza vs. Venezuela, o Juiz Diego García-Sayán assentou, em seu voto concorrente, as possibilidades de extensão das restrições aos direitos políticos, ao permitir a restrição à capacidade eleitoral passiva, desde que seja determinada por autoridade judicial, devendo tal medida ser, necessariamente, proporcional e previsível, não obstante tenha afastado a possibilidade de restrição desses 
direitos humanos fundamentais pela via administrativa, tendo em vista que a dimensão do direito afetado demandava a atual judicial e exorbitava do poder sancionador de âmbito administrativo:

16. [...] Otros espacios judiciales (como la autoridad judicial electoral, por ejemplo) pueden tener, así, legitimidad para actuar. Lo que es claro y fundamental es que cualquiera que sea el camino utilizado debe llevarse a cabo con pleno respeto de las garantías establecidas en la Convención y, además, ser proporcionales y previsibles. 17. A la luz de una interpretación evolutiva y sistemática del artículo 23.2 y en atención al carácter vivo de la Convención, cuya interpretación tiene que acompañar la evolución de los tiempos y las condiciones contemporáneas de la evolución institucional, lo crucial es que sea una autoridad de naturaleza judicial, vale decir en sentido amplio, y no restringida a un juez penal. En este caso la sanción no la impuso una autoridad judicial.

Esta parte do voto caminha no sentido de que não apenas decisões em processos penais possam impor restrições aos direitos políticos, como também às decisões em processos eleitorais e, para além do voto, na apuração da prática de atos dolosos de improbidade administrativa.

Com efeito, decisões em vias administrativas não poderiam ensejar restrições aos direitos políticos do cidadão. A Lei de Inelegibilidades prevê restrições à capacidade eleitoral passiva, isto é, o direito de ser eleito/votado, o jus honorum, como a alínea "g" do inciso I do art. $1^{\mathrm{o} 45}$, cuja (in) convencionalidade será adiante aferida.

45 Art. $1^{\circ}$ São inelegíveis: I - para qualquer cargo: g) os que tiverem suas contas relativas ao exercício de cargos ou funções públicas rejeitadas por irregularidade insanável que configure ato doloso de improbidade administrativa, e por decisão irrecorrível do órgão competente, salvo se esta houver sido suspensa ou anulada pelo Poder Judiciário, para as eleições que se realizarem nos 8 (oito) anos seguintes, contados a partir da data da decisão, aplicando-se o disposto no inciso II do art. 71 da Constituição Federal, a todos os ordenadores de despesa, sem exclusão de mandatários que houverem agido nessa condição; 


\section{Dreitos políticos, o caso Lopez Mendoza vs Venezuela e a (in)convencionalidade da alínea "g" da LC n 64/1990}

A condição dos direitos políticos como direitos humanos fundamentais, estabelecidos, inclusive, na Declaração Universal dos Direitos Humanos de 1948 (art. XXI) e na CADH, de 1969 (art. 23), demonstra a relevância do presente estudo.

Dissertando sobre os direitos humanos como fundamento dos direitos políticos, José Jairo Gomes ${ }^{46}$ destaca a positivação desses direitos em diversos diplomas internacionais, concluindo que:

[...] os direitos políticos situam-se entre os direitos humanos e fundamentais, constituindo um subsistema. o desenvolvimento desse subsistema é sobremodo relevante, pois significa a institucionalização daqueles direitos e dos valores que expressam, e isso é essencial para otimizar a proteção deles.

Ademais, os direitos políticos formam a base do regime democrático ${ }^{47}$.

É competência do STF o controle abstrato de constitucionalidade das leis quando do conhecimento das representações de inconstitucionalidade que versem sobre matéria eleitoral.

O fortalecimento dos direitos políticos no direito interno, por conseguinte, será muito mais eficaz se os tribunais e juízes domésticos travarem o diálogo entre jurisdições. Não obstante, verifica-se que a jurisprudência da Corte Interamericana de Direitos Humanos possui reduzida influência no âmbito interno, para não dizer ignorada.

46 GOMES, 2010, p. 110-113.

47 MENDES; BRANCO, 2012, p. 753. 
É cediço que a LC n ${ }^{0} 64 / 1990$, com as alterações da LC $n^{\circ}$ 135/2010 - Lei da Ficha Limpa -, possui hierarquia normativa inferior aos tratados internacionais de direitos humanos que o Brasil é signatário, em especial a CADH. Como dito, em que pese tenha sido julgada constitucional pelo STF, se houver confronto com dispositivos convencionais - o que se pretende demonstrar aqui -, sua eficácia deve ser esvaziada por meio do controle de convencionalidade, ainda que seja uma norma válida.

No escólio de Valério Mazzuoli ${ }^{48}$, para que exista a vigência e a concomitante validade das leis - no caso da presente pesquisa, a Lei de Inelegibilidades -, deve-se respeitar uma dupla compatibilidade vertical material, a saber: a compatibilidade da lei com a Constituição Federal e os tratados internacionais de direitos humanos vigentes no país; com os demais instrumentos internacionais ratificados pelo Brasil.

Dessa forma, se omitiu o STF de proceder a um duplo controle, ou seja, verificar a compatibilização da Lei da Ficha Limpa com a CADH ou qualquer outro instrumento internacional de proteção dos direitos humanos do qual o Brasil é signatário (bloco de constitucionalidade).

No julgamento das representações de inconstitucionalidade não se tomou como paradigma uma "Constituição convencionalizada", conforme denomina Néstor Pedro Sagués, "aquela depurada de ingredientes anticonvencionais" ${ }^{49}$.

O art. 27 da CADH estabelece que nem mesmo em casos de grave comoção social - guerra, por exemplo - os direitos políticos sofrerão restrições. Por isso, causa espécie a norma insculpida no art. 15 da $\mathrm{CF}^{50}$, a qual prevê a perda e suspen-

48 MAZZUOLI, 2013b, p. 20.

49 FERREIRA, 2015, p. 193-194.

50 Art. 15. É vedada a cassação de direitos políticos, cuja perda ou suspensão só se dará nos casos de:

I - cancelamento da naturalização por sentença transitada em julgado; 
são dos direitos políticos, ainda que vedada sua cassação. No caso específico da recusa de cumprir obrigação a todos imposta ou prestação alternativa (inciso IV) - a objeção de consciência - a suspensão dos direitos políticos carece, de forma inafastável, do parâmetro mínimo convencional.

Flávia Piovesan é objetiva ao cuidar da diferença de tratamento pelos tratados entre direitos civis e políticos e aqueles direitos sociais, econômicos e culturais. Se nestes últimos sua aplicação é progressiva, porque demandam uma forte atuação do Estado, em relação aos direitos políticos, é de se reconhecer que são autoaplicáveis. Mesmo assim, requerem esses direitos, um aparato estatal adequado para sua fruição, sendo inadequada, para Piovesan, a percepção simplista que empresta a mera exigência de prestações negativas do Estado em relação aos direitos políticos. Por isso mesmo, a noção de desenvolvimento progressivo desses últimos é plenamente aceitável ${ }^{51}$.

A objeção que se faz, neste particular, à Lei da Ficha Limpa é, exatamente, em relação ao retrocesso dos direitos políticos, admoestados, solapados, reduzidos e limitados, sob novas formas, maiores prazos de inelegibilidade, com a inclusão de novos sujeitos, totalmente contrário ao caráter progressivo dos direitos humanos, em claro atentado ao desenvolvimento e ao princípio da proibição do retrocesso, conforme Parecer Consultivo $n^{\circ} 4 / 84$ da Corte Interamericana e artigo 26 da $\mathrm{CADH}^{52}$.

II - incapacidade civil absoluta;

III - condenação criminal transitada em julgado, enquanto durarem seus efeitos;

IV - recusa de cumprir obrigação a todos imposta ou prestação alternativa, nos termos do art. $5^{\circ}$, VIII;

$\mathrm{V}$ - improbidade administrativa, nos termos do art. $37, \S 4^{\circ}$.

51 FERREIRA, Op., cit., p. 196.

52 Ibid., p. 196-197. 
O mencionado parecer cuidou de indagação formulada pelo parlamento da Costa Rica, acerca da convencionalidade, nos termos do art. 20 da CADH, de uma emenda à constituição costarriquense, que previa o aumento das restrições à aquisição da nacionalidade naquele país. A Corte IDH entendeu, por unanimidade, que a Costa Rica violou a Convenção, na medida em que estabeleceu situação discriminatória ao criar condições de preferência para a naturalização, em razão do matrimônio em favor de, apenas, um dos cônjuges.

Faz-se mister, para conhecimento, trazer à colação o voto dissidente do juiz Rodolfo Piza acerca da extensão do princípio da proibição do retrocesso aos direitos civis e políticos ${ }^{53}$ :

Es así como los principios de "desarrollo progressivo" contenidos en el artículo 26 de la Convención, si bien literalmente referidos a las normas económicas, sociales y sobre educación, ciencia y cultura contenidas en la Carta de la Organización de los Estados Americanos, deben a mi juicio entenderse aplicabes a cualquiera de los derechos "civiles y políticos" consagrados en la Convención Americana, en la medida y aspectos en que éstos no resulten razonablemente exigibles por sí mismos, y vice versa, que las normas de la propia Convención deben entenderse aplicables extensivamente a los llamados "derechos económicos, sociales y culturales" en la medida y aspectos en que éstos resulten rezonablemente exigibles por sí mismos (como ocurre, por ejemplo, con el derecho de huelga).

Para Ferreira ${ }^{54}$ :

Pode-se dizer que o caminho percorrido, pelo Brasil, no que diz respeito aos direitos políticos não foi o do desenvolvimento progressivo e, sim, foi na direção oposta, a de uma involução ou um desenvolvimento regressivo de limitação dos direitos políticos.

53 Disponível em: http://corteidh.or.cr/index.php/es/opiniones-consultivas. Acesso em 05.set.2015.

54 Ibid., mesma página. 
No Brasil, em nome de moralismos espúrios, os direitos políticos vêm sofrendo restrições e limitações. Não se pode admitir que essa prática se expanda ainda mais, pois mandamentos morais não podem estorvar a ordem jurídica, sob pena de afetar sua estabilidade.

Para tentar comprovar o que se diz, analisaremos a incidência de inelegibilidade do cidadão condenado com base na chamada alínea " $\mathrm{g}$ " do inciso I, do art. $1^{\circ}$, da Lei de Inelegibilidades, cuja redação merece ser transcrita na integralidade para melhor análise do referido dispositivo infraconstitucional, in verbis:

Art. $1^{\circ}$ São inelegíveis:

I - para qualquer cargo:

[...]

g) os que tiverem suas contas relativas ao exercício de cargos ou funções públicas rejeitadas por irregularidade insanável que configure ato doloso de improbidade administrativa, e por decisão irrecorrível do órgão competente, salvo se esta houver sido suspensa ou anulada pelo Poder Judiciário, para as eleições que se realizarem nos 8 (oito) anos seguintes, contados a partir da data da decisão, aplicando-se o disposto no inciso II do art. 71 da Constituição Federal, a todos os ordenadores de despesa, sem exclusão de mandatários que houverem agido nessa condição;

São, portanto, três os requisitos, cumulativos, para a imposição da sanção de inelegibilidade, quais sejam: (i) as contas devem ser rejeitadas por irregularidade insanável; (ii) que configure ato doloso de improbidade administrativa; e (iii) por decisão irrecorrível do órgão competente, salvo se esta houver sido suspensa ou anulada pelo Poder Judiciário. Impende notar que na falta de apenas um desses requisitos, a imposição de inelegibilidade cai por terra, visto que, como dito, são cumulativos. É imprescindível, portanto, que além do ato atacado estar eivado de irregularidade insanável, configure ato doloso de improbidade administrativa, 
é dizer, quando o ato for praticado com culpa, ou quando a irregularidade for sanável, não se cogita apenar o gestor público com a sanção da alínea "g".

Até o ano de 2016, a rejeição das contas de gestor por Tribunal de Contas atraia a incidência da alínea " $\mathrm{g}$ ". Inobstante o fato de eles possuírem a mais alta relevância republicana, no seu mister de órgão fiscalizador do Poder Executivo, auxiliando o Legislativo, bem como o fato de que possuem autonomia frente à ordem constitucional, suas decisões não podem gerar inelegibilidade, como disposto na alínea " $\mathrm{g}$ ", pois, como estabelecido no art. 23.2 da CADH, somente decisões judiciais podem restringir direitos políticos, prolatadas por juiz competente em processo penal.

Os Tribunais de Contas, na ordem constitucional brasileira, não integram o Poder Judiciário; não exercem, portanto, atividade jurisdicional. Suas decisões não possuem caráter definitivo, cabendo ao Judiciário proferir a última palavra, inobstante o fato de que suas decisões fazem coisa julgada administrativa.

Cyrineu $^{55}$ lembra o seguinte:

A análise das Cortes de Contas restringe-se à questão contábil, embora haja muito de juridicidade em suas decisões. Entretanto, a própria forma com que se dá a tramitação dos julgamentos das contas dos ordenadores de despesa, em comparação com um procedimento judicial (ação de improbidade ou ação, por exemplo), evidenciam a precariedade de garantias necessárias a legitimar a imposição de óbice ao sufrágio passivo.

Percebe-se, pois, que a falta de garantias de ampla defesa e contraditório torna a decisão dos Tribunais de Contas precária, inapta a impor óbice ao jus honorum do gestor pú-

55 CYRINEU, Rodrigo Terra. Direitos Políticos como categoria de Direitos Humanos e sua necessária adequação ao Sistema Interamericano de Direitos Humanos, 2016, p. 18. 
blico. Somente um processo judicial de garantias, com ampla possibilidade instrutória, é capaz de produzir um édito condenatório legítimo, apto a restringir direitos políticos.

Faz-se mister ressaltar que não cabe às Cortes de Contas a verificação da existência no caso concreto de irregularidade insanável ou se aquele ato se reveste de desonestidade tal, que configure ato de improbidade. No primeiro caso a competência é reconhecidamente da Justiça Eleitoral; no segundo, é da Justiça Comum. Tal circunstância dificulta o trabalho da defesa, que, em sede de processo administrativo perante o Tribunal de Contas, terá que fazer menção à não configuração de ato doloso de improbidade, para que o gestor não fique inelegível.

Com efeito, esse fato não é o mais grave na lente da Convenção Americana. A Constituição Federal - em seu art. 49, IX - atribui a competência para o julgamento das contas do Prefeito, por exemplo, ao parlamento municipal, tendo o Tribunal de Contas função meramente opinativa (art. 71, I, da CF), à exceção dos casos em que a competência é a de julgamento de contas relativas a convênios.

Tal fato levou o STF a reconhecer, em 10 de agosto de 2016, no julgamento dos RE 848826 e 729744, que discutiam qual o órgão competente - se Câmara dos Vereadores ou Tribunal de Contas - para julgar as contas de Prefeitos, e se a desaprovação das contas pelo Tribunal de Contas gera inelegibilidade, em caso de omissão do Poder Legislativo municipal. O STF, em repercussão geral, entendeu que a competência para julgar as contas do Prefeito é da Câmara dos Vereadores, não incidindo, por conseguinte, a inelegibilidade da alínea "g" a partir da desaprovação pelo Tribunal de Contas, necessitando, para tanto, da ratificação da desaprovação pelo legislativo local. É dizer, o parecer da Corte de Contas é meramente prévio e opinativo e somente poderá 
ser derrubado por decisão de 2/3 dos Vereadores. O STF assentou, igualmente, que em caso de omissão da Câmara Municipal, a inelegibilidade não incide.

Em virtude de o processo de julgamento do Chefe do Executivo ser eminentemente político, corre-se o risco de, mesmo tendo parecer favorável do Tribunal de Contas - não apontando, por exemplo, qualquer irregularidade, por não possuir maioria no parlamento -, ter suas contas rejeitadas e, consequentemente, ser imposta sanção de inelegibilidade.

É cediço que o parlamento sequer possui corpo técnico especializado como os Tribunais de Contas, cujos julgamentos, ainda que administrativos, são, em tese, técnicos e não políticos.

Torquato Jardim ${ }^{56}$, sobre o tema, apresenta a seguinte dimensão da questão:

O juízo legislativo, particularmente no julgamento de contas, é o mais eminentemente político, é o que menos carece de fundamentação, porque é quando a minoria política afirma sua posição em face da maioria. É um juízo político onde se afirma a minoria política, em face da Administração. Mudada a composição de cadeiras do Poder Legislativo, não raro, sucede uma nova votação, cuja motivação, por ser juízo político, não judiciável, escapa do Poder Judiciário.

$\mathrm{Na}$ esteira do autor supracitado, muito mais incompatível com a CADH é o julgamento político proferido pelo Parlamento.

A Corte Interamericana, no Caso Lopez Mendoza vs. Venezuela, assentou a impossibilidade de imposição de sanção de inabilitação - inelegibilidade, no Brasil - ao autor por decisão prolatada por autoridade administrativa, no caso, a Controladoria-Geral da República da Venezuela, nas eleições de 2008.

56 JARDIM, 1998, p. 80. 
O senhor Lopez Mendoza foi inabilitado para o exercício de funções públicas e segundo alegou à época houve uma sistemática persecução política para disseminar inelegibilidades aos opositores do regime, sob a roupagem de combate à corrupção, com clarividente intenção de expurgar do pleito eleitoral os opositores nas eleições daquele ano, um atentando a qualquer regime que se intitule minimamente de democracia ${ }^{57}$.

O Conselho Nacional Eleitoral da Venezuela aprovou normas para as eleições, as quais afastavam a elegibilidade de candidatos considerados interditados ou inabilitados para o exercício de funções públicas, medida administrativa esta que expurgou mais de 400 pessoas da participação do processo de escrutínio público.

Impende trazer à colação excerto da decisão tomada pela Corte IDH no caso em comento, a saber:

107. El artículo 23.2 de la Convención determina cuáles son las causales que permiten restringir los derechos reconocidos en el artículo 23.1, así como, en su caso, los requisitos que deben cumplirse para que proceda tal restricción. En el presente caso, que se refiere a una restricción impuesta por vía de sanción, debería tratarse de una "condena, por juez competente, en proceso penal". Ninguno de esos requisitos se ha cumplido, pues el órgano que impuso dichas sanciones no era un "juez competente", no hubo "condena" y las sanciones no se aplicaron como resultado de un "proceso penal", en el que tendrían que haberse respetado las garantías judiciales consagradas en el artículo 8 de la Convención Americana.

108. La Corte estima pertinente reiterar que "el ejercicio efectivo de los derechos políticos constituye un fin en sí mismo y, a la vez, un medio fundamental que las sociedades democráticas tienen para garantizar los demás derechos humanos previstos en la Convención y que sus titulares, es decir, los ciudadanos, no sólo deben gozar de derechos, sino también de "oportunidades". Este último

57 DAHL, 2015. 
término implica la obligación de garantizar con medidas positivas que toda persona que formalmente sea titular de derechos políticos tenga la oportunidad real para ejercerlos. En el presente caso, si bien el señor López Mendoza ha podido ejercer otros derechos políticos (supra párr. 94), está plenamente probado que se le ha privado del sufragio pasivo, es decir, del derecho a ser elegido.

109. En virtud de lo que antecede, la Corte determina que el Estado violó los artículos 23.1.b y 23.2 en relación con el artículo 1.1 de la Convención Americana, en perjuicio del señor Leopoldo López Mendoza..$^{58}$

Da decisão, extrai-se a necessidade de condenação por juiz competente em processo penal, conforme preconizado pela $\mathrm{CADH}$, nos termos do seu art. $8^{\circ}$ - devido processo convencional -, bem como destacou os contornos do direito humano fundamental em questão, assentando ser ele meio fundamental nas sociedades democráticas para a garantia dos demais direitos, devendo serem asseguradas medidas positivas para que o titular dos direitos políticos tenha oportunidade real de exercê-los.

Ademais, a Corte IDH reconheceu, no mesmo caso, violação às garantias convencionais de contraditório efetivo e de motivação convincente das decisões, senão vejamos ${ }^{59}$ :

149. En consecuencia, el Estado es responsable por la violación del deber de motivación y el derecho a la defensa en los procedimientos administrativos que derivaron en la imposición de las sanciones de inhabilitación, establecidos en el artículo 8.1, en relación con el artículo 1.1 de la Convención Americana sobre Derechos Humanos, en perjuicio del señor López Mendoza. ${ }^{60}$

Comentando o excerto, conclui Cyrineu ${ }^{61}$ :

58 Decisão disponível em: http://corteidh.or.cr/docs/casos/articulos/seriec_233_esp.pdf. Acessado em: 01 jul. 2016.

59 CYRINEU, Op. Cit., p. 19.

60 Idem.

61 CYRINEU, Op. Cit., mesma página. 
Daí o porquê de ser salutar a análise da irregularidade detectada pelo Tribunal de Contas em sede de ação de improbidade administrativa, sobretudo porque as sanções previstas na Lei $n^{\circ} 8.429 / 1992$ não são automáticas e, portanto, são passíveis de gradação pelo magistrado na fixação da pena, atendendo, portanto, às exigências da Convenção Americana tocante à necessária fundamentação da gravíssima sanção de suspensão dos direitos políticos.

Nessa senda, outro caso importante analisado pela Comissão Interamericana de Direitos Humanos no qual restou provada a violação às normas convencionais foi o caso Petro Urrego vs. Colômbia. Gustavo Francisco Petro Urrego, então candidato a Prefeito de Bogotá, teve seus direitos políticos suspensos por uma decisão administrativa, de natureza disciplinar, emitida pela Procuradoria-Geral da Nação, a qual lhe inabilitou para durante quinze anos para o exercício de funções públicas, por conta de alegadas irregularidades cometidas quando Petro Urrego exerceu o cargo de Prefeito naquela cidade.

Em março de 2014, a Comissão Interamericana de Direitos Humanos concedeu medida provisional, suspendendo a decisão administrativa até ulterior deliberação sobre a matéria de fundo, medida que fora acolhida pelo Estado Colombiano. No parecer a CIDH ressaltou a importância de se observar os parâmetros convencionais para restringir direitos políticos. Em outubro de 2017, a CIDH julgou procedente a pretensão do peticionante, consignando a impossibilidade de decisões administrativas ou políticas restringirem direitos políticos, recomendando ao Estado Colombiano:

1. Deixar sem efeito os atos administrativos sancionatórios que impuseram sanções de inabilitação ao Senhor Gustavo Francisco Petro Urrego, de forma tal que possa exercer livremente seus direitos políticos, incluindo seu direito ao sufrágio passivo; (...) 3. Adequar sua legislação interna, em particular, as disposições da Constituição política e Código Disciplinar Único, que contemplam respectivamente a faculdade de destituir e inabilitar funcionário 
de eleição popular por parte da Procuradoria Geral da Nação no exercício de sua potestade disciplinar; 4 . Adequar a norma penal para assegurar que não se incluam referências à via disciplinar ou fiscal nos tipos penais relacionados à eleição de pessoas inabilitadas. Em todo o caso, o Estado deve abster-se de aplicar o tipo penal previsto no artigo 5 da Lei n. 1834 de 2017, levando em consideração as determinações sobre a inconvencionalidade da destituição disciplinar ou fiscal, sem condenação penal transitada em julgado ("firme"). ${ }^{62}$

Sobre este caso, Jorge Alejandro Amaya ${ }^{63}$ obtempera:

Los órganos decisorios de la CADH [...] han fijado lineamientos que sirven de guía para interpretar el alcance de los derechos políticos en los Estados. En virtud del control de convencionalidad, estos lineamientos vinculan a los diversos actores estatales - entre otros, los administrativos e judiciales - encargados de la tutela de los derechos fundamentales.

Na esteira de tudo o que foi aqui debatido, conclui-se ser a alínea " $\mathrm{g}$ " inconvencional, pois afronta legislação internacional de proteção dos direitos humanos e da interpretação conformada pela Corte IDH em matéria de direitos políticos.

O mesmo raciocínio deve ser aplicado aos processos de julgamento de contas pelos Tribunais de Contas, aos procedimentos disciplinares dos conselhos profissionais, aos processos administrativos instaurados pela Administração Pública e aos julgamentos de agentes políticos pelas Casas Legislativas, seja em sede de prestação de contas, seja por quebra de decoro parlamentar.

\section{Conclusão}

A transcrição do que preleciona Eneida Desiree Salgado ${ }^{64}$ é inevitável, quando alerta que:

62 FERREIRA; ORTIZ, 2017.

63 AMAYA, 2016, p. 275.

64 SALGADO; ARAÚJO, 2013, p. 121-148. 
A "Lei da Ficha Limpa" é símbolo de um perigoso encontro entre discurso jurídico e moralidade - uma moralidade perniciosa que desafia os fundamentos do Estado Democrático de Direito e que contraria os princípios da legalidade, da irretroatividade de restrições aos direitos fundamentais, da proteção e da confiança.

Inobstante a LC 135/2010 ter sobrevivido ao crivo de constitucionalidade pelo STF, olvidou o Alto Tribunal de realizar o duplo controle, analisando a (não) adequação da Lei da Ficha Limpa aos dispositivos convencionais trazidos no corpo da CADH. Sob pena de constrangimento da nação brasileira, para evitar que se torne rotineira a condenação do Estado brasileira pela Corte IDH, deve o Supremo Tribunal Federal tomar como parâmetro os textos convencionais e realizar o reexame da referida legislação complementar.

São precisas as lições de Ferreira quando aduz que:

Hoje, em pleno regime democrático, vive-se em torno de padrões de comportamento e contornos da inelegibilidade criados, exatamente, para suprimir e abafar o pluralismo político, permitindo o afastamento de candidatos sob os mais variados argumentos entoados no mesmo cântico desafinado da "moralidade" e da sua "vida pregressa", conforme Artigo 151 da Constituição de 1967 [trazido para a CF/88 - art. 14].

O julgamento no controle concentrado de constitucionalidade pelo STF é só mais um contraste à observância dos dispositivos convencionais pela ordem interna. No caso da "Guerrilha do Araguaia", também houve dissonância entre as decisões prolatadas pelas diferentes ordens jurídicas.

Não são as leis eleitorais que mudarão o caótico cenário político atual. O povo não precisa da tutela exagerada do Estado, como se não fosse capaz de escolher seus representantes. Ao povo, num regime democrático, é dado o direito de escolher, inclusive, maus representantes. 
Se encaixa como uma luva, nesse sentido, o que prelecionam Aliomar Baleeiro e Barbosa Lima Sobrinho ${ }^{65}$.

Por isso não são poucas as vozes, que se mostram descrentes da eficácia das leis eleitorais. Já em 1875, Pedro II escrevia a Rio Branco, dizendo-lhe: cada vez me entristeço mais do que tem sido, e serão ainda por muito tempo, adotem-se as medidas que se adotarem, as eleições entre nós. Não é o vestido, observava o Imperador que tornará vestal a Messalina, porém, sim, a educação do povo e, portanto, do Governo.

Este estado de desconfiança foi apontado no final do século passado, na década de 1990, por Torquato Jardim ${ }^{66}$ quando dissertava sobre a reelegibilidade, alertava para a situação de desabono dos direitos políticos, senão vejamos:

[...] A cultura estabelecida na Constituição, nas leis, nos tribunais e na sociedade civil é de presunção negativa para com o candidato a cargo eletivo: toda a construção legislativa e jurisprudencial é para restringir e controlar seus atos. Assim o prazo de desincompatibilização, as inelegibilidades por parentesco, a noção de abuso do poder econômico ou de autoridade, as limitações ao uso frequente de franquias parlamentares, e até há pouco, a irreelegibilidade. Num ambiente em que a desconfiança começa na Constituição, passa por uma lei complementar de inelegibilidade, por uma lei ordinária geral com normas dúbias sobre a conduta dos agentes públicos candidatos e pela jurisprudência, até chegar à opinião pública e à mídia, a tarefa dos chefes dos executivos candidatos à reeleição e de seus conselheiros de construírem uma nova versão de democracia eletiva constitui um desafio notável.

Precisamos, todos, de educação política e não de leis eleitorais que imponham limitações e restrições aos direitos políticos, reconhecidos que são como direitos humanos fundamentais. Quem perde, com essa prática, é a democracia.

65 BALEEIRO, 2012, p. 38-39.

66 JARDIM, 1998, p. 117. 
Especificamente em relação ao controle de constitucionalidade exercido pelo STF, Eneida Desiree Salgado e Eduardo Borges ${ }^{67}$ não vislumbram fundamento constitucional para a moralidade:

Nada permite afirmar que a Constituição Federal de 1988 é compatível com uma leitura moralizadora e perfeccionista. O Texto Constitucional, embora traga valores compartilhados pela sociedade, como a solidariedade e a igualdade, não aniquila o espaço de liberdade e nem apresenta um projeto de vida boa a ser imposto aos cidadãos. O compartilhamento de valores públicos, expresso no preâmbulo e no artigo $3^{\circ}$, revela uma moralidade objetiva que não autoriza a imposição de uma moralização subjetivada, seja pelo legislador ou pelos magistrados, em nome de prevenção ou precaução.

Impende consignar que, no mês de novembro de 2015, foi apresentada representação contra a Lei da Ficha Limpa perante a Comissão Interamericana de Direitos Humanos, pelos advogados catarinenses Ruy Samuel Espíndola e Marcelo Ramos Peregrino, na defesa do ex-prefeito Odilon Vicente de Lima (PSD), eleito Prefeito do Município de Campo Erê em 2012, porém teve seus votos anulados porque, em 2004, foi condenado à prisão pelo Tribunal de Justiça de Santa Catarina. Mesmo sem trânsito em julgado, a Lei da Ficha Limpa torna inelegíveis candidatos condenados em órgão colegiado pela prática de crimes contra a administração pública ${ }^{68}$.

Alega o reclamante, dentre outros fundamentos, violação à presunção de inocência e ao devido processo convencional, retroatividade maligna da LC 64/90, alterada pela LC 135/2010, contagem dos prazos de inelegibilidade.

67 SALGADO; ARAÚJO, Op. cit., p. 121-148.

68 Disponível em: http://www.conjur.com.br/2015-nov-28/lei-ficha-limpa-questionada-comissao-interamericana-oea. Acesso em: 29 nov. 2015. 
Tal medida de vanguarda coloca a legislação eleitoral brasileira no centro dos debates internacionais acerca da violação do direito fundamental e político à candidatura.

Por fim, resta-nos acompanhar a evolução do debate da matéria em âmbito nacional e internacional e suas consequências para o direito interno, de modo que a legislação doméstica seja conformada aos ditames dos tratados internacionais de direitos humanos.

\section{Referências}

AGRA, Walber de Moura. Temas polêmicos de direito eleitoral. Belo Horizonte: Fórum, 2012.

ALAMAR, Edgar Moreira. Controle judicial de convencionalidade no Tribunal de Justiça do Estado do Pará. 2015. 191 f. Dissertação (Mestrado em Direito) - Universidade Federal do Pará, Instituto de Ciências Jurídicas, Programa de Pós-graduação em Direito, Belém, 2015.

AMAYA, Jorge Alejandro. Los derechos políticos. 1 ed. Buenos Aires: Astrea, 2016.

BALEEIRO, Aliomar; SOBRINHO, Barbosa Lima. Constituições brasileiras. A Constituição de 1946. 3 ed. Brasília: Senado Federal, 2012.

BASTOS JUNIOR, Luiz Magno Pinto; CAMPOS, Thiago Yukio Guenka. Para além do debate em torno da hierarquia dos tratados: do duplo controle vertical das normas internas em razão da incorporação dos tratados de direitos humanos. RFD - Revista da Faculdade de Direito da UERJ, v. 1, n. 19, jun./ dez 2011.

BOBBIO, Norberto. Teoria Geral do Direito. São Paulo: Martins Fontes, 2007. 
CANÇADO TRINDADE, Antônio Augusto. Tratado de Direito Internacional dos Direitos Humanos. v.1. 2. ed. ver. e atual. Porto Alegre: Sergio Antonio Fabris, 2003.

. A interação entre o Direito Internacional e o Direito Interno na proteção dos direitos humanos. In: A incorporação das normas internacionais de proteção dos direitos humanos no direito brasileiro. 2 ed. San José: IIDH, 1996, p. 211.

COELHO, Bernardo Leôncio Moura. O bloco de constitucionalidade e a proteção à criança. Revista de Informação Legislativa, Brasília, v. 31, n. 123, p. 259-266, jul./ set. 1994.

CORTE INTERAMERICANA DE DIREITOS HUMANOS. Caso Tibi vs. Equador. Exceções Preliminares, Mérito, Reparações e Custas. Sentença de 7 de setembro de 2004. Disponível em: < http://www.corteidh.or.cr/index.php/ en/decisions-and-judgments>. Acesso em: 05 set. 2015.

CYRINEU, Rodrigo Terra. Direitos Políticos como categoria de Direitos Humanos e sua necessária adequação ao Sistema Interamericano de Direitos Humanos. Fundação Escola Superior do Estado do Mato Grosso: 2016.

DAHL, Robert. Poliarquia: participação e oposição. 1 ed. 3 reimp. São Paulo: Edusp, 2015. (Clássicos, 9).

FAVOREU, Louis. El bloque de la constitucionalidad. Revista del Centro de Estudios Constitucionales, n. 4, p. 45-68, jan./mar. 1990.

FERREIRA, Marcelo Ramos Peregrino. O controle de convencionalidade da lei da ficha limpa. Rio de Janeiro: Lumen Juris, 2015.

FERREIRA, Marcelo Ramos Peregrino; ORTIZ, Julio. Ficha Limpa e caso Petro Urrego: controle de convencionalidade 
das inelegibilidades. Disponível em: https://www.conjur. com.br/2017-dez-02/ ficha-limpa-petro-urrego-mostram-controle-inelegibilidades. Acesso em: 06 nov. 2018.

FERRER MAC-GREGOR, Eduardo. Interpretación conforme y control difuso de convencionalidad: El nuevo paradigma para el juez mexicano. Estudios constitucionales, Santiago, v. 9, n. 2, 2011. Disponível em: <http://www.scielo.cl/scielo. php?script=sci_arttext\&pid=S0718-52002011000200014\&lng =es\&nrm=iso $>$. Acesso em: 20nov. 2015.

GOMES, José Jairo. Direitos Políticos. Revista Brasileira de Estudos Políticos, Belo Horizonte, n. 100, p. 103-130, jan./ jun. 2010.

JARDIM, Torquato. Direito Eleitoral Positivo. Brasília: Brasília Jurídica, 1998.

KELSEN, Hans. Teoria Pura do Direito. 8 ed. São Paulo: Martins Fontes, 2009.

LUCHETE, Felipe. Lei da Ficha Limpa é questionada em comissão de Direitos Humanos da OEA. Disponível em: http:/ / www.conjur.com.br/2015-nov-28/lei-ficha-limpa-questionada-comissao-interamericana-oea. Acesso em: 29 nov. 2015.

MARÍN, Roselia Bustilo. El control de convencionalidad: la idea del bloque de constitucionalidad y su relación con el control de constitucionalidad en materia electoral. México. Tribunal Electoral del Poder Judicial de la Federación. 2013. Disponível em <http://www.te.gob.mx/ccje/ Archivos/Control_de_Convencionalidad.pdf $>$. Acesso em: 01 set. 2015.

MAUÉS, Antonio Gomes Moreira. O controle de constitucionalidade das leis no Brasil como um sistema plural. Pensar, Fortaleza, v. 15, n. 2, p. 356-384, jul./dez. 2010. 
Supralegalidade dos tratados internacionais de direitos humanos. SUR. Revista Internacional de Direitos Humanos, v. 10, n. 18, p. 215-235, jun. 2013.

MAZZUOLI, Valério de Oliveira. O controle jurisdicional da convencionalidade das leis. 2. ed. São Paulo: Revista dos Tribunais, 2011.

O controle jurisdicional da convencionalidade das leis. 3. ed. São Paulo: Revista dos Tribunais, 2013a.

Teoria geral do controle de convencionalidade no direito brasileiro. In: MARIRONI, Luiz Guilherme; MAZZUOLI, Valério de Oliveira (Coord.) Controle de convencionalidade: um panorama latino-americano: Brasil, Argentina, Chile, México, Perú, Uruguai / Calogero Pizzolo ... [et. Al.]; 1 ed. Brasília, DF : Gazeta Jurídica, 2013b.

MENDES, Gilmar Ferreira; BRANCO, Paulo Gustavo Gonet. Curso de direito constitucional. 7 ed. São Paulo: Saraiva, 2012.

PIOVESAN, Flávia. Direitos humanos e diálogo entre jurisdições. Revista Brasileira de Direito Constitucional RBDC n. 19, p. 67-93, jan./jun. 2012.

Direitos humanos e o direito constitucional internacional. 15. ed., rev. e atual. São Paulo: Saraiva, 2015. SALGADO, Eneida Desiree; ARAÚJO, Eduardo Borges. Do legislativo ao judiciário: a Lei Complementar nº 135/2010 ("Lei da Ficha Limpa"), a busca pela moralização da vida pública e os direitos fundamentais. A\&C - Revista de Direito Administrativo \& Constitucional, Belo Horizonte, ano 13, n. 54, p. 121-148, out./dez. 2013.

SARLET, Ingo Wolfgang. Comentário ao artigo $5^{\circ}, \S 2^{\circ}$. In: CANOTILHO, J.J. Gomes; MENDES, Gilmar F; STRECK, 
Lenio L.; (Coords). Comentários à Constituição do Brasil. São Paulo: Saraiva/Almedina, 2013. TEREZO, Cristina Figueiredo. Sistema interamericano de direitos humanos: pela defesa dos direitos econômicos, sociais e culturais. 1. ed. Curitiba: Appris, 2014.

Recebido em 24/07/2018.

Aprovado em 16/10/2018.

\section{Sandro Alex de Souza Simões}

E-mail:prof.sandroalex@gmail.com

Pedro Henrique Costa de Oliveira

E-mail:pedrohco@hotmail.com 